\title{
DIVERSI SEBAGAI PERLINDUNGAN HUKUM TERHADAP HAK ASASI ANAK DALAM SISTEM PERADILAN PIDANA ANAK DI INDONESIA
}

\author{
Beniharmoni Harefa \\ Mahasiswa Pascasarjana Program Doktor FH UGM Yogyakarta \\ E-mail : bencit@rocketmail.com
}

\begin{abstract}
ABSTRAK
Kenakalan anak (juvenile delinquency) tidak sama dengan kejahatan orang dewasa. Penanggulangan kenakalan anak harus bertolak dari pemahaman yang tepat. Pemahaman ini utamanya didasarkan dengan melihat faktor penyebab mengapa anak menjadi nakal. Tulisan ini mencoba mengupas upaya penanggulangan kenakalan anak menggunakan pendekatan kriminologi. Tiga teori kriminologi yang digunakan sebagai pisau analisis, yakni teori differential association, teori kontrol sosial dan teori labeling. Diversi atau pengalihan yang dikenal dalam Sistem Peradilan Pidana Anak berperan sebagai upaya penanggulangan kenakalan anak. Diversi menghindari anak belajar perilaku jahat, memperbaiki hubungan anak dengan masyarakat, menghindari stigmatisasi/ cap jahat pada anak. Beberapa hal ini menegaskan diversi sebagai upaya penanggulangan kenakalan anak (juvenile delinquency) perspektif kriminologi.
\end{abstract}

Kata Kunci : Diversi, Kenakalan Anak, Keadilan Restoratif

\section{ABSTRACT}

Juvenile Delinquency is not the same as adult crime. The prevention of juvenile delinquency must begin with right understanding. This understanding is based, primarily, by looking at the causes of why children become naughty. This paper attempts to review the efforts to prevent juvenile delinquency by applying criminology approach. There are three criminology theories which are used as the knife analysis, namely the Theory of Differential Association, Theory of Social Control and the Theory of Labeling. The diversion which is known in the Juvenile Justice System acts as junevile delinquency prevention efforts. Diversion prevents children from learning malicious behavior, improves the children relationship with the community, and hinders bad stigmatization/labelling to the children. These things explains that diversion is a Juvenile Delinquency prevention effort from criminology perspective.

Keywords : Diversion, Juvenile Delinquency, Restorative Justice

\section{Pendahuluan}

Permasalahan terkait anak selalu menarik untuk diperbincangkan. Kiranya masih segar diingatan beberapa kasus yang menyita perhatian publik beberapa tahun lalu. Kasus seperti pemenjaraan anak usia 8 tahun bernama Raju di StabatSumatera Utara (http://www.ypha.or.id/web/?tag=Pra ktek-praktek-sistem-peradilan-pidanaanak.doc ), kasus pencurian sandal jepit yang dilakukan AAL di Palu, kasus anak-anak bermain judi di bandara Soekarno-Hatta (Muhammad ;2012). Kasus-kasus di atas menjadi perhatian khalayak, disebabkan penyelesaian perbuatan menyimpang anak, diselesaikan melalui jalur peradilan pidana formal. 
Penanganan dan penanggulangan yang salah terhadap anak pelaku tindak pidana, akan berdampak pada terganggunya program dalam rangka menyiapkan anak-anak, sebagai generasi penerus bangsa. Tidak dapat dinafikan, menempatkan anak pelaku tindak pidana di dalam proses peradilan formal, memberikan dampak buruk bagi perkembangan dan kehidupan anak.

Dampak buruk berupa trauma, stigma/ label jahat, dan dikeluarkan dari sekolah (Setya;2009), akan diterima anak, apabila ditempatkan dalam sistem peradilan pidana formal. Hal ini berpotensi melanggar hak-hak asasi mereka, bahkan tidak jarang dijumpai, anak justru memiliki keterampilan kriminal luar biasa, setelah keluar penjara, karena pergaulan dengan sesama tahanan maupun orang dewasa (Elfina;2012).

Saat anak ditempatkan dalam proses peradilan pidana formal, tidak jarang ditemukan perlakuan seperti : pemukulan, penyiksaan, atau tindakan lain yang kejam dan tidak manusiawi lainnya. Memang tidak semua anak dan juga tidak semua aparat penegak hukum bertindak buruk seperti itu, namun sebagai rangkaian proses, sistem peradilan pidana (penyelidikan/ penyidikan, penuntutan, pemeriksaan di pengadilan) berpotensi melanggar hak-hak dasar anak.

Berdasarkan hasil penelitian Paulus Hadisuprapto, bentuk-bentuk tindakan buruk lainnya yang harus diterima anak yang ditempatkan dalam proses peradilan pidana formal, seperti : dibentak, dimaki, digunduli rambutnya, ditampar, disulut rokok, ditempatkan di tahanan campur dengan pelaku kejahatan orang dewasa. Hal ini erat kaitannya, karena perilaku aparat penegak hukum di Indonesia khususnya pihak Kepolisian, masih mempunyai kebiasaan mengejar pengakuan (Hadisuprapto;2003).

tersangka

Selain fisik, pengaruh psikologis atau kejiwaan juga akan berdampak negatif pada anak, akibat proses peradilan pidana. Pengalaman menjalani rangkaian proses peradilan yang melelahkan, akan berbekas di dalam ingatan anak. Efek negatif itu dapat berupa ketakutan, kegelisahan, gangguan tidur, gangguan nafsu makan maupun gangguan jiwa.

Sebagai akibat menempatkan anak dalam proses peradilan pidana formal, anak menjadi gelisah, tegang, kehilangan kontrol emosional, menangis, gemetaran, malu, dan sebagainya. Efek negatifpun berlanjut setelah anak dijatuhi putusan pemidanaan, seperti stigma yang berkelanjutan (Apong;2004).

Berbagai dampak atau pengaruh negatif, sebagai akibat diperhadapkannya anak dengan proses peradilan pidana formal tersebut, merupakan pelanggaran atas hak-hak dasar/ asasi anak. Pelanggaran hak asasi anak inipun terjadi, sejak dimulainya proses peradilan terhadap dirinya (anak). Anak tetap harus mempertanggungjawabkan perbuatan menyimpangnya, namun tanpa harus dilanggar hak-haknya.

Memahami posisi anak sebagai generasi penerus, maka diperlukan pembinaan dan perlindungan khusus (Nashriana;2011). Anak harus mendapat perhatian khusus, pertimbangan khusus, pelayanan dan perlakuan/ perawatan khusus serta perlindungan khusus. Karena perlindungan anak sangatlah luas, maka perlindungan yang dimaksud yakni perlindungan hukum/ yuridis 
(legal protection) (Barda;2010). Perlindungan hukum (legal protection) terhadap anak, diperlukan, agar anak mendapatkan perhatian dari kesalahan penerapan peraturan perundangundangan yang diberlakukan terhadap dirinya, yang menimbulkan kerugian mental, fisik, dan sosial.

Dari uraian di atas terlihat, bahwa berbagai dampak buruk berpotensi dihadapi anak, apabila ditempatkan dalam proses peradilan pidana formal. Hal ini akan melanggar hak-hak asasi mereka (anak). Oleh sebab itu, diperlukan suatu terobosan untuk menghindarkan anak, dari proses peradilan pidana formal itu. Terobosan yang dimaksud, diperlukan untuk memberikan perlindungan terhadap hak-hak asasi anak. Agar tidak bias makna, maka anak yang dimaksud dalam penulisan ini adalah anak yang telah berumur 12 (dua belas) tahun, tetapi belum berumur 18 (delapan belas) tahun yang diduga melakukan tindak pidana. Terobosan yang diperlukan salah satunya dengan konsep diversi. Diversi dapat dipahami sebagai upaya untuk mengalihkan proses penyelesaian perkara pidana anak, dari proses peradilan pidana formal ke luar proses peradilan pidana (non formal) (Marlina;2013) Peradilan pidana non formal salah satunya dengan jalan musyawarah.

Tulisan ini hendak menegaskan perihal peran penting diversi (pengalihan) dalam sistem peradilan pidana anak, sehingga perlu pengembangan. Selain mempunyai peran penting untuk memberikan perlindungan hukum terhadap hak-hak asasi anak, diversi juga menemui kelemahan. Kelemahan-kelemahan ini perlu mendapat perhatian, guna pengembangan diversi di masa mendatang. Agar di masa mendatang, penyelesaian perkara pidana anak melalui jalur diversi semakin memberikan keadilan, kemanfaatan dan kepastian hukum bagi kepentingan terbaik anak (the best interest of the child).

\section{Diversi Memberikan Perlindungan Hukum Bagi Hak Asasi Anak}

Indonesia baru secara tegas mengakomodir proses penyelesaian perkara pidana anak melalui jalur diversi, di tahun 2012. Ketentuan diversi diatur melalui Undang-Undang Nomor 11 Tahun 2012 tentang Sistem Peradilan Pidana Anak (UU SPPA). Berdasarkan UU SPPA, diversi bertujuan untuk mencapai perdamaian antara korban dan anak, menyelesaikan perkara anak di luar proses peradilan, menghindarkan anak dari proses perampasan kemerdekaan, mendorong masyarakat untuk berpartisipasi, dan menanamkan rasa tanggungjawab kepada anak.

Berikut skema pelaksanaan diversi pengalihan sebagai bentuk penyelesaian perkara pidana anak : 
Skema: Diversi Dalam Sistem Peradilan Pidana Anak
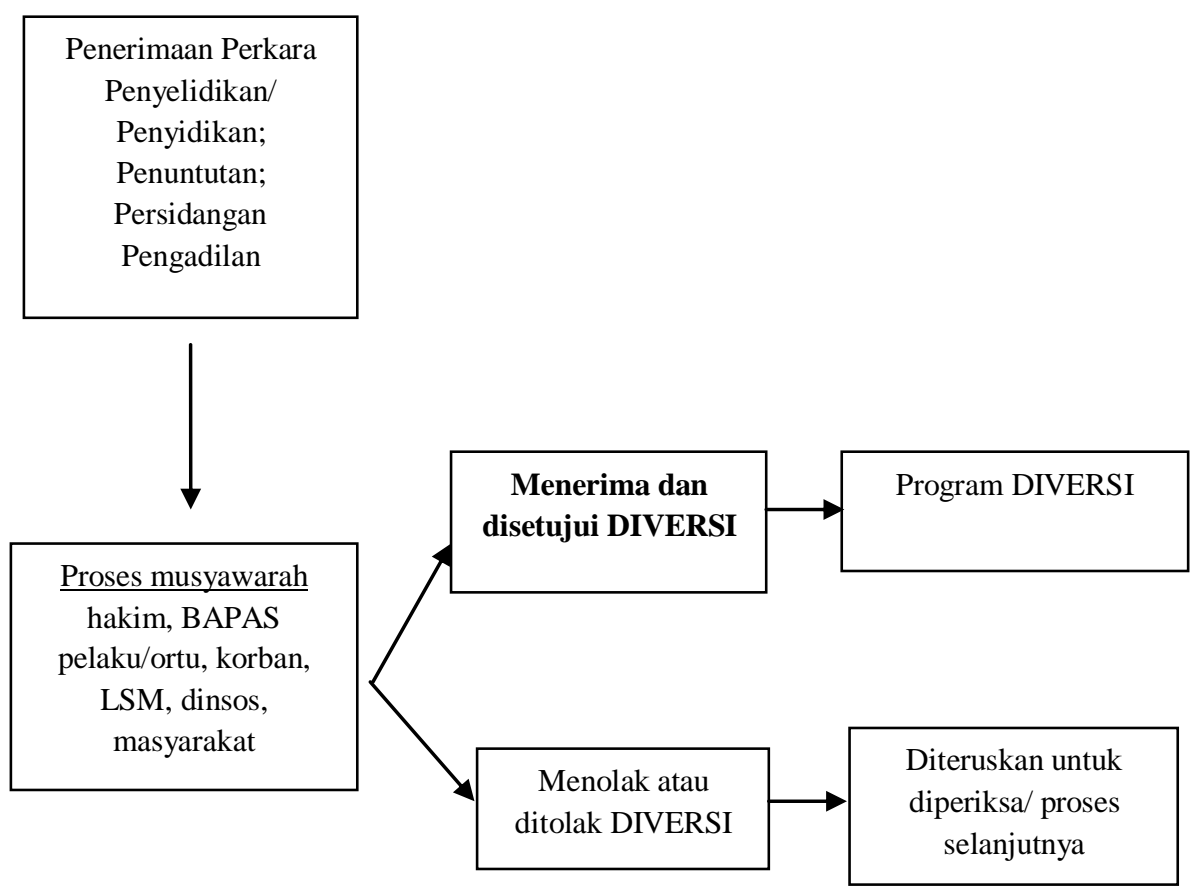

Peran penting diversi (pengalihan) sangat dirasakan utamanya dalam memberikan perlindungan terhadap hak-hak asasi anak. Saat anak melakukan tindak pidana, maka harus ada penyelesaian. Penyelesaian perkara melalui jalur peradilan pidana formal, mempunyai dampak buruk dalam perkembangan anak sebagaimana telah dijelaskan sebelumnya. Sejak saat penyelidikan/ penyidikan di kepolisian hak-hak anak berpotensi dilanggar. Berlanjut pada tahap penuntutan oleh penuntut umum hingga sidang di pengadilan.

Pada sidang di pengadilan anak berpeluang besar dijatuhi sanksi pidana atau sanksi tindakan. Bahkan dampak buruk berlanjut disaat anak berada di lembaga pemasyarakatan. Sekolah kejahatan dan stigmatisasi berpotensi didapatkan anak. Oleh sebab itu, menempatkan anak dalam proses peradilan pidana formal harus dihindari, karena melanggar hak-hak asasi anak. 
Skema: Diversi Dalam Sistem Peradilan Pidana Anak

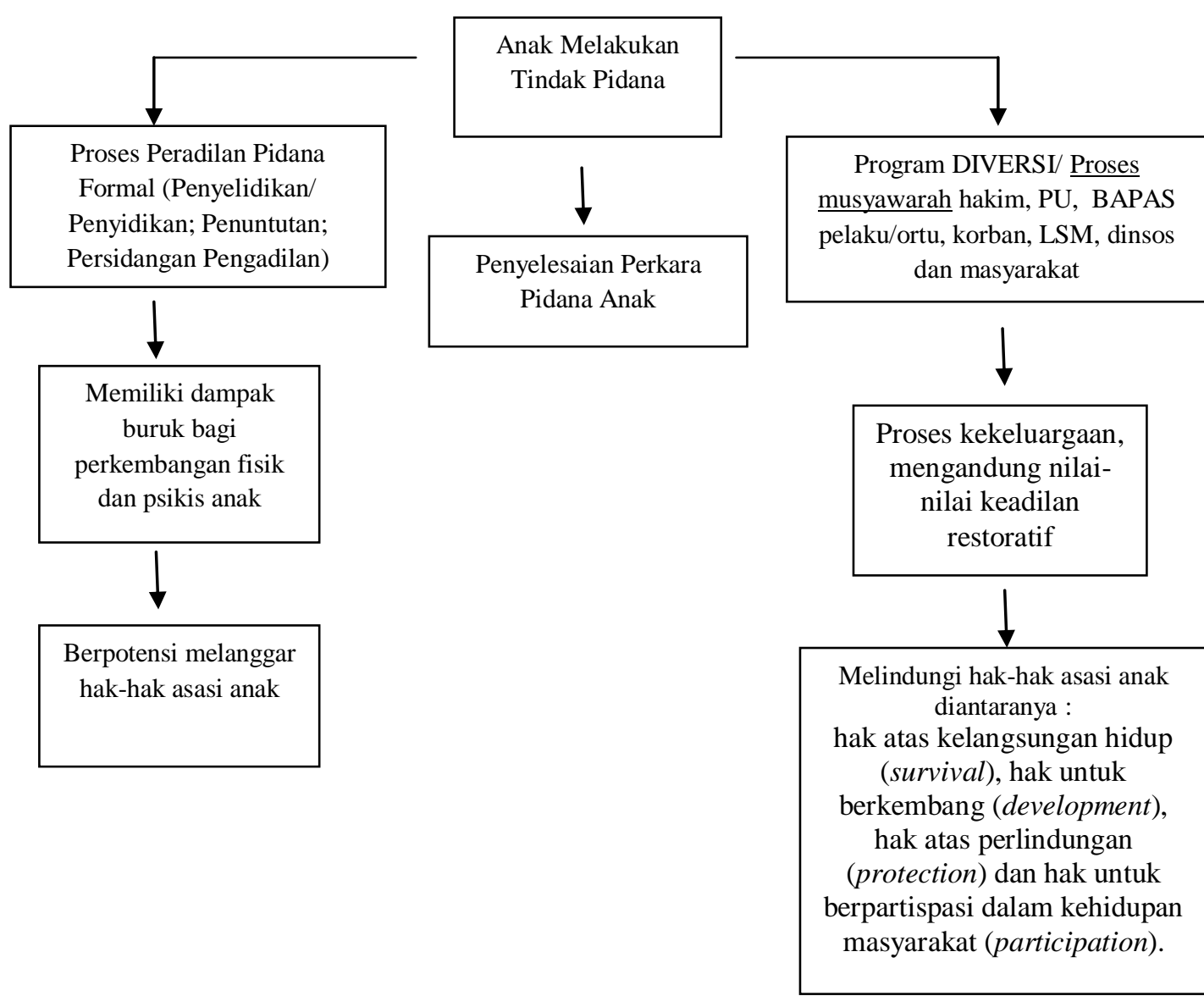

Demi kepentingan terbaik anak (the best interest of the child)

Penyelesaian perkara pidana anak melalui jalur diversi, dilakukan dengan penuh nilai-nilai kekeluargaan. Oleh sebab itu, diversi akan menjauhkan anak dari dampakdampak buruk yang dapat menyebabkan terganggunya perkembangan dan masa depan anak. Diversi kiranya lebih memperhatikan hak-hak asasi anak.

Adapun 4 (empat) cakupan hak asasi (hak dasar) anak, yang dirumuskan di dalam Convention on the Rights of the Child (Farid ;2003)
(Konvensi Hak-Hak Anak) yaitu : hak atas kelangsungan hidup (survival), hak untuk berkembang (development), hak atas perlindungan (protection) dan hak untuk berpartispasi dalam kehidupan masyarakat (participation).

Pertama, peranan diversi sebagai upaya perlindungan hak kelangsungan hidup (survival). Tindakan penyelidikan/ penyidikan, penuntutan, pemeriksaan di pengadilan, bahkan di lembaga pemasyarakatan anak, tentunya akan mengganggu kelangsungan hidup 
anak. Tindakan dan perilaku aparat dengan menginterogasi, menyelidik, investigasi sangat melekat dalam pikiran anak. Hal ini sangat mengganggu kelangsungan hidupnya. Diversi (pengalihan) menjadi suatu upaya yang sangat berarti untuk menghindarkan anak dari tindakan yang melanggar hak kelangsungan hidup anak.

Kedua, peranan diversi sebagai upaya perlindungan hak untuk berkembang (development). Berkembang dalam arti yang lebih luas seperti mendapatkan pendidikan, pengajaran, informasi, dan sebagainya. Proses peradilan pidana formal memberi kewenangan bagi penegak hukum untuk melakukan penangkapan dan penahanan. Penangkapan, penahanan anak, akan mengganggu sekolah, dan kesempatan lainnya untuk belajar misalnya kursus atau les pelajaran di luar jam sekolah. Diversi (pengalihan) menjadi suatu upaya yang sangat berarti untuk menghindarkan anak dari tindakan yang menghambat perkembangan anak.

Ketiga, peranan diversi sebagai upaya perlindungan hak atas perlindungan (protection). Pada saat anak berhadapan dengan proses peradilan pidana formal, maka dapat dipastikan anak akan kehilangan kebebasannya. Dengan dialihkan, maka kebebasan anak tetap terjamin, dan perampasan kemerdekaan terhadap mereka dapat dihindari. Diversi (pengalihan) menjadi suatu upaya yang sangat berarti untuk memberikan perlindungan (protection) bagi anak.

Keempat, peranan diversi sebagai upaya perlindungan hak untuk berpartisipasi dalam kehidupan masyarakat (participation). Partisipasi yang dimaksud dalam berbagai hal, misalnya dalam bergaul, berinteraksi, mengeluarkan pendapat dalam lingkungan sosialnya. Dengan menjalani proses peradilan pidana (tanpa diversi), kesempatan anak berinteraksi, bergaul dengan masyarakat akan terganggu. Adanya diversi, akan mendorong masyarakat tidak sempat memberikan stigma/ cap negatif terhadap anak. Diversi mempunyai peranan penting dalam memberikan perlindungan bagi hak asasi khususnya hak untuk berpartisipasi dalam kehidupan masyarakat (participation).

Konsep diversi ini sangat relevan dengan semangat keadilan restoratif (restorative justice). Bahkan ada yang secara tegas menyatakan, bahwa salah satu bentuk proses restorative adalah diversi (Achjani;2014). Restorarative justice bermaksud menggeser paradigma pemikiran yang berkembang selama ini dalam sistem peradilan pidana anak. Bahwa selama ini, pemidanaan didasarkan pada pemahaman yang bersifat pembalasan (retributif) (Sambas, 2010) sehingga difokuskan pada pelaku anak saja. Hukuman (pemidanaan) bagi seorang, bukan merupakan balas dendam, tetapi harus merupakan suatu bentuk pendidikan untuk mencegahnya melakukan kejahatan lagi di masa depan (Hartono, 1991).

Restorative justice merupakan filsafat, proses, ide, teori dan intervensi yang menekankan memperbaiki kerugian yang disebabkan atau diungkapkan oleh perilaku criminal (Puji;2012). Hal ini relevan dengan konsep diversi (pengalihan) yang berusaha 
mengalihkan proses penyelesaian perkara pidana anak ke luar peradilan formal, sebagai upaya pemulihan bagi anak terhadap korban dan masyarakat.

Dalam model peradilan restoratif, aparat penegak hukum memfasilitasi bertemunya tersangka dengan korban untuk merumuskan skema penyelesaian yang terbaik dan dianggap adil oleh pihak-pihak yang bersengketa (Marcus;2013).

Menurut ahli kriminologi kebangsaan Inggris Tony F. Marshall, menyatakan bahwa restorative justice is a process whereby all the parties with a stake in a particular offence come together to resolver collectively how to deal with the aftermath of the offence and its implications for the future (Allison ;p.5) (restorative justice adalah suatu proses dimana semua pihak yang berkepentingan di dalam pelanggaran tertentu, bertemu bersama untuk menyelesaikan secara bersama, guna menyelesaikan akibat dari pelanggaran yang terjadi demi kepentingan masa depan). Marshall mendefenisikan restorative justice dengan membuat segitiga restorative justice, sebagai berikut :

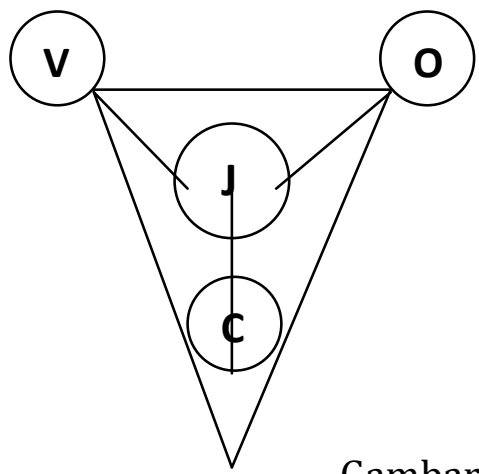

Keterangan :

$\mathrm{V}$ : Victim (korban)

$\mathrm{O}$ : Offender (pelaku)

C : Community (lingkungan)

J : Justice (keadilan)

Berdasarkan defenisi yang dikemukakan oleh Tony F. Marshall, menurut Susan Sharpe, ada 5 (lima) prinsip utama dari restorative justice, yaitu :

1. Restorative justice invites full participation and consensus (restorative justice mengandung partisipasi penuh dan konsensus)

2. Restorative justice seeks to heat with is broken (restorative justice berusaha menyembuhkan kerusakan/ kerugian yang ada akibat terjadinya tindakan kejahatan).

3. Restorative justice seeks full and direct accountability (restorative justice memberikan pertanggungjawaban langsung dari pelaku secara utuh).

4. Restorative justice seeks to recinite what has been devided (restorative justice mencarikan penyatuan kembali kepada warga masyarakat yang telah terpisah atau terpecah karena tindakan kriminal).

5. Restorative justice seeks to strengthen the community in order to prevent further harms (restorative justice memberikan ketahanan kepada masyarakat agar dapat mencegah terjadinya tindakan kriminal berikutnya).

Bentuk praktik restorative justice yang telah berkembang di negara Eropa, Amerika Serikat, Canada, Australia dan New Zealand, 
dapat dikelompokkan dalam 4 (empat) jenis praktik yang menjadi pioneer penerapan restorative justice dibeberapa negara, yaitu (Marlina, 2012) :

1. Victim Offender Mediation,

2. Conferencing/ Family Group Conferencing,

3. Circles,

4. Restorative Board/Youth Panels.

Praktik diversi juga sudah sejak lama dipraktikkan dalam peradilan anak di negeri Belanda (Hadisuprapto, 2006) Karakteristik hukum pidana anak Belanda didasarkan pada asas pedagogik. Peraturan perundang-undangan pidana anak Belanda diatur dalam Bab VII A Ketentuan Khusus untuk Anak Buku I Wetboek van Strafrecht$S r$. Ketentuan itu terdapat dalam pasal $77 \mathrm{a}$ s/d 77gg Sr. termasuk ketentuan diversi.

Diversi

(pengalihan)

dilaksanakan dalam bentuk transaksi oleh polisi dengan anak pelaku tindak pidana. Transaksi polisi dengan anak ini terwujud dalam bentuk kerjasama dengan biro HALT (Het Alternatief). Contoh kegiatan biro HALT, kasusnya menyangkut seorang anak bernama $B$ mencuri barang di Mall. Perbuatan B diketahui petugas keamanan mall yang bersangkutan, dan ditangkap selanjutnya diserahkan kepada polisi.

Atas dasar pemahaman polisi, perbuatan B memenuhi syarat untuk diikut sertakan program HALT. Transaksi yang ditawarkan oleh polisi diterima oleh B dan orangtuanya. Petugas HALT kemudian memanggil $B$ beserta orangtuanya, pemilik mall (korban) dan polisi, dilaksanakanlah musyawarah untuk menentukan "sanksi" untuk B. Kesepakatan dihasilkan bahwa : B harus mengembalikan barang yang telah dicurinya kepada pemilik mall dan untuk menebus kesalahannya si B harus membersihkan lantai mall selama 2 bulan, yang pengerjaannya dilakukan tiap akhir minggu selama 2 jam, yang waktunya bebas ditentukan sendiri oleh B, sesuai dengan waktu luangnya.

Konsep diversi yang menerapkan nilai-nilai keadilan restoratif bukanlah barang baru bagi masyarakat Indonesia. Program ini telah banyak dilakukan oleh kepala desa atau kepala adat, untuk menyelesaikan konflik yang terjadi antar warga masyarakat (Marcus). Bila dilihat secara historis kultur (budaya), masyarakat Indonesia sangat menjunjung tinggi pendekatan konsensus (musyawarah dan mufakat) (Mushadi, 2007).

\section{Pengembangan Diversi}

Melihat peran penting diversi dalam memberikan perlindungan hak asasi anak, maka diversi perlu dikembangkan. Salah satu contoh perkara pidana anak yang diselesaikan melalui jalur diversi (pengalihan). Perkara terjadi pada tahun 2012, di wilayah hukum Kepolisian Resort (Polres) Nias. Ketika dua orang anak yang tertangkap melakukan perbuatan nakal yakni pencurian, diselesaikan secara kekeluargaan bersama pihak korban dan masyarakat. Anak berinisal AT berumur 15 tahun dan RH berumur 16 tahun, keduanya tertangkap oleh warga dan diserahkan ke pihak Polres Nias, karena melakukan pencurian sepeda motor di halaman parkir sebuah Rumah Sakit.

Kedua anak nakal difasilitasi untuk bertemu langsung dan 
menjelaskan duduk perkara kepada pihak korban. Pertemuan dilakukan dengan menghadirkan kedua anak, orang tua masing-masing, dan pihak korban serta disaksikan oleh perwakilan tokoh masyarakat dan didampingi lembaga perlindungan anak. Dalam pertemuan tersebut kedua anak, mengakui dan menyesali perbuatannya, serta tanpa diperintah meminta maaf kepada korban dan keluarga. Kesepakatan pun tercapai, keluarga korban mau memaafkan pelaku, dan kedua anak menandatangani surat perjanjian tidak mengulangi perbuatannya. Anak-anak tersebut kembali melanjutkan sekolah dan tidak pernah mengulangi perbuatan nakalnya lagi.

Proses diversi (pengalihan) yang dilakukan melalui musyawarah, dengan melibatkan anak dan orangtua/walinya, pembimbing kemasyarakatan, dan pekerja sosial profesional berdasarkan pendekatan keadilan restorative (lihat UU SPPA Pasal 8 ayat (1)). Dalam hal diperlukan, musyawarah sebagaimana dimaksud dapat melibatkan tenaga kesejahteraan sosial, dan/ atau masyarakat (Pasal 8 ayat 2, UU SPPA).

Skema : Para Pihak Dalam Proses Penyelesaian Perkara Melalui Jalur Diversi

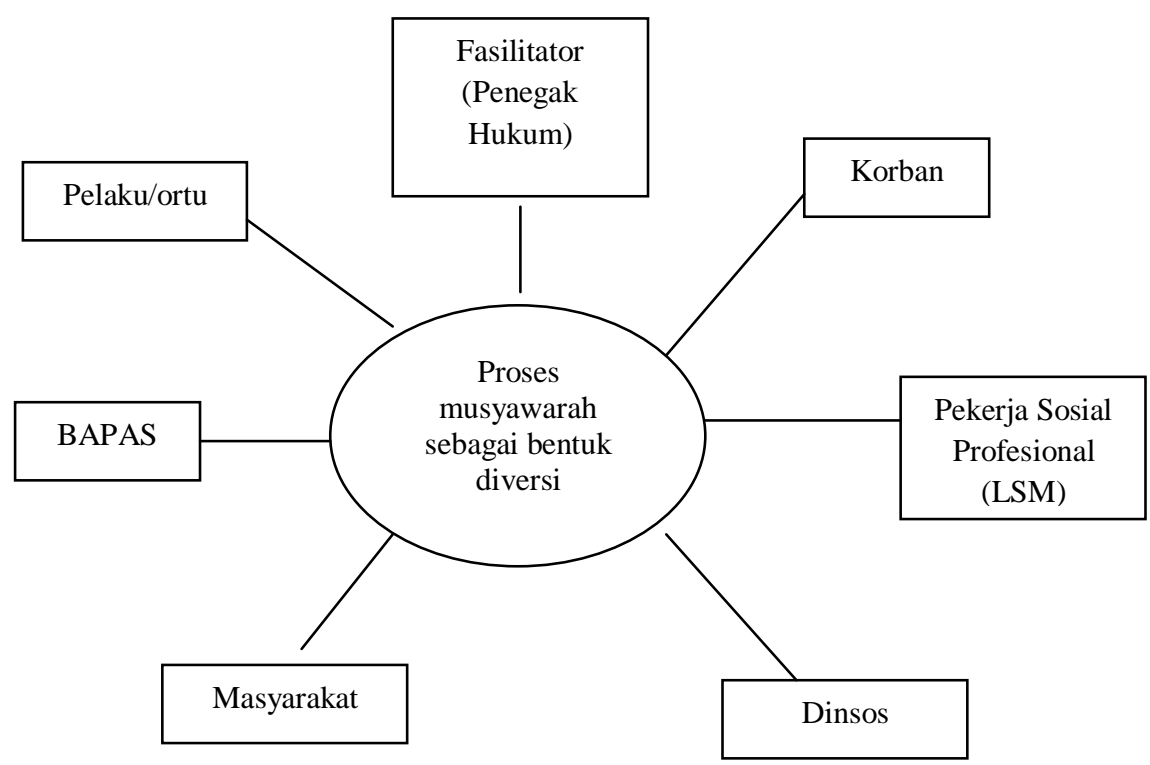

Pengembangan diversi perlu dilakukan mengingat diversi dalam musyarah penuh dengan nilai-nilai kekeluargaan. Hal ini memberikan perlindungan terhadap hak-hak asasi anak. Memahami peran pentingnya diversi dan perlu dikembangkan, maka beberapa negara-negara yang telah melaksanakan diversi. 
Negara-negara yang telah melaksanakan Diversi (Elfina;2012) :

\begin{tabular}{|c|c|}
\hline Fiji & 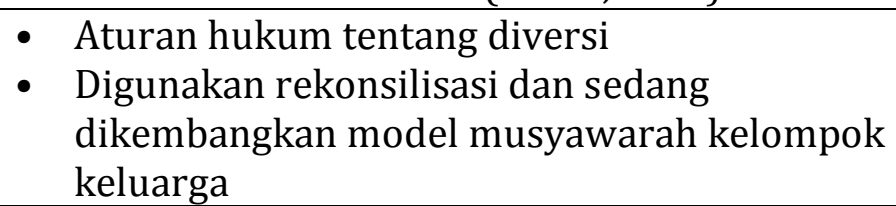 \\
\hline Filipina & $\begin{array}{l}\text { - Konsiliasi dan mediasi sering digunakan } \\
\text { - UU Peradilan Anak tentang Restorative Justice } \\
\text { (2003) termasuk mediasi, konsiliasi, dan } \\
\text { musyawarah kelompok keluarga sebagai } \\
\text { alternatif selain pengadilan } \\
\text { - Dalam UU tersebut juga disebutkan bahwa } \\
\text { diversi dapat dilaksanakan pada tingkat desa, } \\
\text { polisi, dan kejaksaan }\end{array}$ \\
\hline Papua New Guinea & UU Diversi berlaku 1991 \\
\hline Republik Laos & $\begin{array}{ll}\text { - } & \text { Mediasi paling sering digunakan } \\
\text { - } & \text { Re-edukasi ada dalam Hukum Adat }\end{array}$ \\
\hline Thailand & $\begin{array}{l}\text { - Konsiliasi dan mediasi sering digunakan } \\
\text { - Rencana penyusunan UU Peradilan Anak } \\
\text { termasuk musyawarah kelompok keluarga }\end{array}$ \\
\hline Timor Timur & $\begin{array}{l}\text { - Mediasi dalam Hukum Adat } \\
\text { - Gereja biasa terlibat dalam proses diversi }\end{array}$ \\
\hline
\end{tabular}

Kendati mempunyai peran penting, tidak berarti diversi tidak mempunyai kelemahan. Penulis mencoba membagi kelemahan diversi dalam tiga tahap yakni pada tahap proses diversi, pada tahap diversi gagal, dan pada tahap diversi berhasil.

Pertama, pada tahap proses diversi. Sebagaimana telah disampaikan diatas bahwa musyawarah sebagai bentuk diversi, melibatkan beberapa pihak. Para pihak duduk bersama untuk mengambil kesepakatan. Hasil musyawarah sebagai hasil kesepakatan bersama, menjadi bentuk pertanggungjawaban anak, sehingga tidak ditempatkan dalam proses peradilan pidana formal.
Hasil kesepakatan sangat bergantung pada para pihak yang terlibat dalam musyawarah, utamanya korban. Hal ini berpotensi menimbulkan ketimpangan atau ketidakseimbangan kedudukan pelaku (anak) dengan korban. Hal ini sangat erat kaitannya perihal bentuk pertanggungjawaban anak, dalam penyelesaian perkara pidana melalui jalur diversi. Apabila ketidakseimbangan atau ketimpangan itu terjadi, maka bukan tidak mungkin terjadi tarik menarik kepentingan dan para pihak memanfaatkan kesempatan.

Pihak keluarga korban yang meyakini dirinya mempunyai posisi tawar (bergaining positition) lebih tinggi dari posisi pelaku, dalam proses musyawarah, berpotensi 
menyalahgunakan kesempatan. Pihak anak (keluarga pelaku) seolah menjadi pihak yang tidak mempunyai pilihan selain tunduk pada keputusan pihak korban sebagai bentuk kesepakatan yang dapat membebaskan pelaku dari jalur peradilan formal.

Kedua, pada tahap diversi gagal. Musyawarah sebagai bentuk diversi dalam penyelesaian perkara pidana, tidak selalu berhasil. Kendati telah dilaksanakan musyawarah, kesepakatan selalu tercapai. Apabila hal ini terjadi, diversi gagal dan perkara pidana anak dikembalikan pada proses peradilan pidana formal. Namun demikian, hasil musyawarah yang berlangsung sebagai upaya diversi yang gagal itu, dapat digunakan pihak tertentu (korban atau penegak hukum) untuk dijadikan alat bukti pada proses peradilan pidana berikutnya (jika diversi gagal maka dapat dipastikan proses penyelesaian perkara pidana anak kembali ke proses peradilan pidana formal).

Hasil musyawarah yang dimaksud misalnya berupa faktafakta perihal tindak pidana anak, pengakuan anak (tersangka), seharusnya tidak boleh digunakan dalam proses peradilan pidana berikutnya (proses peradilan pidana formal), karena berpotensi akan memperberat sanksi terhadap anak bila selanjutnya ditempatkan dalam proses peradilan formal (karena diversi gagal). Hasil musyawarah tersebut kiranya dianggap tidak pernah ada. Namun dengan telah dilaksanakannya musyawarah (kendati gagal), tidak dapat dinafikan hasil musyawarah tersebut justru akan memperberat posisi anak pada proses peradilan pidana formal.
Ketiga, pada tahap diversi berhasil. Apabila kesepakatan telah tercapai sesuai hasil musyawarah, maka diversi berhasil. Anak mempertanggungjawabkan perbuatan menyimpangnya, tanpa harus ditempatkan dalam proses peradilan pidana formal. Hasil musyawarah dapat dipastikan memuat beberapa kesepakatan yang harus dipenuhi oleh para pihak. Para pihak yang dimaksud, baik pelaku (anak), korban, dan masyarakat serta pihak lainnya harus tunduk, menaati, serta memenuhi hasil kesepakatan sebagai hasil musyawarah bersama.

Namun demikian, permasalahan muncul jika para pihak utamanya anak (pelaku) dan korban tidak menaati, memenuhi, dan tunduk pada hasil kesepakatan dimaksud. Apabila salah satu pihak tidak menaati hasil kesepakatan tersebut, maka dapat dipastikan hasil musyawarah cacat. Para pihak kembali akan mempermasalahkan perkara pidana anak, dan berpotensi untuk dikembalikan pada proses peradilan pidana formal.

Sejumlah kelemahan diversi sebagaimana disampaikan diatas, disebabkan karena diversi merupakan upaya pengalihan membutuhkan keseragaman pandangan akan hakekat menghindarkan anak dari proses peradilan pidana formal. Oleh sebab itu, dibutuhkan keseragaman pemahaman masyarakat, kepercayaan kepada aparat penegak hukum, serta kemampuan mediator untuk menengahi permasalahan.

Beberapa hal ini perlu dipikirkan bersama dalam hal pengembangan diversi di masa mendatang, karena diversi disamping mempunyai peran penting, diversi 
mempunyai kelemahan. Diversi sangat diperlukan dan dipertahankan keberadaannya dalam proses penyelesaian perkara pidana anak. Oleh sebab itu, pengembangan diversi perlu dilakukan, dengan kepentingan terbaik anak (the best interest of the child) sebagai pertimbangan utama.

\section{Simpulan}

Dari uraian di atas, maka dapat disimpulkan : pertama, diversi sesuai dengan nilai-nilai keadilan restorative justice, sesuai dengan nilai-nilai masyarakat Indonesia dalam menyelesaikan perkara yang menjunjung tinggi musyawarah dan mufakat. Kedua, diversi mempunyai peranan penting dalam memberikan perlindungan atas hak-hak asasi anak. Ketiga, diversi masih menemui kendala dalam penerapannya,diantaranya karena diselesaikan melalui proses

\section{Daftar Pustaka}

Allison Moris and Gabrielle Maxwell, 2001, Restorative Justice For Juvenile : Conferencing, Mediation and Circles, Hart Publishing, Oxford-Portland, Oregon.

Apong Herlina, dkk, 2004, Perlindungan Terhadap Anak yang Berhadapan Dengan Hukum, Manual Pelatihan untuk Polisi, POLRI dan UNICEF, Jakarta.

Elfina L. Sahetapy, "Restorative Justice Dalam Wujud Diversi : Kasus Anak Yang Berkonflik Dengan Hukum", Agustinus Pohan, dkk (ed.), 2012, Hukum Pidana Dalam Perspektif, Universitas Leiden, Universitas Groningen dan Universitas Indonesia bekerjasama dengan Pustaka Larasan, Denpasar. musyawarah maka kedudukan/ posisi para pihak tidak seimbang, hasil musyawarah dapat disalahgunakan dan daya paksa untuk menaati hasil kesepakatan berbeda dibanding daya paksa proses peradilan pidana formal.

Diversi perlu dipertahankan bahkan perlu dikembangkan agar semakin memberikan jaminan terhadap perlindungan hukum atas hak-hak asasi anak dalam sistem peradilan pidana anak di Indonesia. Kelemahan-kelemahan diversi perlu mendapat perhatian, guna pengembangan diversi di masa mendatang. Agar di masa mendatang, penyelesaian perkara pidana anak melalui jalur diversi semakin memberikan keadilan, kemanfaatan dan kepastian hukum bagi kepentingan terbaik anak (the best interest of the child).

Hadi Supeno, 2010, Kriminalisasi Anak : Tawaran Gagasan Radikal Peradilan Anak Tanpa Pemidanaan, Gramedia Pustaka Utama, Jakarta.

Kuat Puji Prayitno, Restorative Justice Untuk Peradilan di Indonesia (Perspektif Yuridis Filosofis Dalam Penegakan Hukum In Concreto), Jurnal Dinamika Hukum Vol. 12 No.3 September 2012.

Maidin Gultom, 2008, Perlindungan Hukum Terhadap Anak Dalam Sistem Peradilan Pidana Anak di Indonesia, Refika Aditama, Bandung.

Marcus Priyo Gunarto, Restrukturisasi Peradilan Pidana Sebagai Upaya Mencegah Kelebihan Kapasitas Narapidana di Lembaga 
Pemasyarakatan, Pidato Pengukuhan Guru Besar, pada Fakultas Hukum Universitas Gadjah Mada, Yogyakarta, pada tanggal 24 Desember 2013.

Marlina, 2012, Peradilan Pidana Anak di Indonesia Pengembangan Konsep Diversi dan Restorative Justice, Refika Aditama, Bandung.

Marlina, Konsep Diversi dan Restorative Justice Dalam UU No 11 Tahun 2012 tentang Sistem Peradilan Pidana Anak, makalah disampaikan pada workshop tentang Restorative Justice dalam Perspektif UU Sistem Peradilan Anak dan Kearifan Lokal Masyarakat Nias, Hotel Nasional, Gunungsitoli, 21 Mei 2013.

Muhammad Joni, 2012, Penjara (Bukan) Tempat Anak, Perhimpunan Advokasi Anak Indonesia (Peran Indonesia), Jakarta.

Muladi dan Barda Nawawi Arief, 2010, Bunga Rampai Hukum Pidana, Alumni, Bandung.

Mushadi, 2007, Mediasi dan Resolusi Konflik di Indonesia, Walisongo Mediation Center, Semarang.

M. Farid,dkk, 2003, Pengertian Konvensi Hak Anak, UNICEF.

Nandang Sambas, 2010, Pembaruan Sistem Pemidanaan Anak di Indonesia, Graha Ilmu, Yogyakarta.

Nashriana, 2011, Perlindungan Hukum Pidana bagi Anak di Indonesia, Raja Grafindo Persada, Jakarta.

Paulus Hadisuprapto, 1997, Juvenile Delinquency Pemahaman dan Penanggulangannya, Citra Aditya, Bandung.
Paulus Hadisuprapto, Pemberian Malu Reintegratif Sebagai Sarana Non Penal Penanggulangan Perilaku Delinkuensi Anak (Studi Kasus di Semarang dan Surakarta), Disertasi Ilmu Hukum, Universitas Diponegoro, Semarang.

Paulus Hadisuprapto, 2006, Peradilan Restoratif : Model Peradilan Anak Indonesia Masa Datang, Pidato Pengukuhan Guru Besar dalam Bidang Kriminologi, Fakultas Hukum Universitas Diponegoro, Semarang, 18 Februari 2006.

Setya Wahyudi, Johannes Suhardjana, Kuat Puji Prayitno, Dwi Hapsari Retnaningrum, Pengembangan Diversi Dalam Sistem Peradilan Pidana Anak sebagai Perlindungan dan Upaya Menghindari Pengaruh Buruk Proses Peradilan Terhadap Anak, Jurnal Kertha Wicaksana, Vol. 15 No. 1, Januari 2009.

Sunaryati Hartono, 1991, Politik Hukum Menuju Satu Sistem Hukum Nasional, Alumni, Bandung.

Tim Yayasan Pemantau Hak Anak, (Children's Human Rights Foundation), Praktek-Praktek Penanganan Anak Berkonflik Dengan Hukum Dalam Kerangka Sistem Peradilan Pidan Anak (Juvenile Justicce System) di Indonesia, http://www.ypha.or.id/web/?ta $\mathrm{g}=$ Praktek-praktek-sistemperadilan-pidana-anak.doc., diakses pada tanggal 08 Januari 2014 pukul 11.00 WIB. 